\title{
1 SOS employability: a support structure 1 for language students
}

\author{
Eleanor Quince ${ }^{1}$, James Minney², \\ Charlotte Medland ${ }^{3}$, and Francesca Rock ${ }^{4}$
}

Abstract

$\mathrm{t}$ is readily recognised that "study and residence abroad are significant
contexts for second language learning and development" (Mitchell, TracyVentura, \& McManus, 2015, p. 1), but the Year Abroad (YA) also provides Modern Foreign Language (MFL) students with a unique opportunity to develop personal and professional skills. YA students go through what is often termed a 'transformative experience' (British Academy/UCML, 2012). However, the problem of skills self-recognition and articulation remains. Without strong support structures students struggle to understand these skills and how to talk about them. This case study explores the creation of an employability-focussed support structure for MFL undergraduate students centred on preparing for, getting the most out of, and articulating the 'soft skills' learnt from the YA. The study presents evidence from three core activities: 1) interviews with YA returners, now final-year students; 2) support through tailored employability modules; and 3) the launch of an interactive online resource for students who are on their YA.

Keywords: year abroad, transformative, employability, skills development, reflection, languages.

\footnotetext{
1. University of Southampton, Southampton, United Kingdom; E.M.Quince@soton.ac.uk

2. University of Southampton, Southampton, United Kingdom; J.D.Minney@soton.ac.uk

3. University of Southampton, Southampton, United Kingdom; C.J.Medland@soton.ac.uk

4. University of Southampton, Southampton, United Kingdom; F.Rock@soton.ac.uk
}

How to cite this chapter: Quince, E., Minney, J., Medland, C., \& Rock, F. (2016). SOS employability: a support structure for language students. In E. Corradini, K. Borthwick and A. Gallagher-Brett (Eds), Employability for languages: a handbook (pp. 123-132). Dublin: Research-publishing.net. http://dx.doi.org/10.14705/rpnet.2016.cbg2016.473 


\section{Context and rationale}

The very nature of the YA - unfamiliar surroundings, distance from friends and relatives, change in work/study culture - means that students need to adapt and assimilate quickly.

Recent 'skills lists', issued by bodies such as the Council for Industry and Higher Education (AGR/CIHE, 2011), draw attention to a variety of complex 'soft skills' which employers look for in potential employees: confidence, initiative, resilience, flexibility, self-motivation/drive. These skills are often categorised as 'personal skills' and, as they tend to be developed through 'experience', can be very difficult for students to master (Havergal, 2015). This difficulty is further compounded by the struggle to readily define and identify the skills: what is 'resilience'?; how does someone know that they are 'resilient'?; - and the problem of articulation - how do you evidence 'resilience' in your CV, personal statement, or at an interview? Students feel more confident talking about their academic achievements rather than their personal skills.

Students' time abroad accelerates their professional development alongside their language proficiency. Staff comment on the change: YA returners are more confident, engaged, and receive criticism more readily; in essence, they have begun to develop the skills employers are looking for, and the YA acts as evidence of this. However, the problem of skills self-recognition and articulation remains (Leggott \& Stapleford, 2004; Small \& Deakin Crick, 2008). Without strong support structures, students struggle to understand these skills and how to talk about them.

To overcome this, researchers and students at the University of Southampton have established a framework to support MFL students in advance of, and on return from, the YA:

- First, interviews with returning YA students established how confident they were about presenting their professional development. 
- Second, the results of these interviews informed the creation of two Employability Modules and an employability-focussed online resource, responding to the problem of skills self-recognition and articulation. The Year Two employability module encourages the use of an e-portfolio to record and articulate skills developed through experience, an activity which can be continued during the YA and implemented through the Final Year module.

- Third, the Residence and Employment Abroad Leading to International Employability (REALIE) website provides peer-to-peer support, advice and links to resources, including monthly blogs by current YA students - selected from an open application round.

\section{Aims and objectives}

The overarching aim of this initiative was the creation of an employabilityfocussed support structure for undergraduate MFL students.

The objectives of the initiative are to:

- assess feedback from YA returners on the soft skills they feel they have developed during the YA;

- identify common issues centred around articulating soft skills development;

- prepare students for soft skills development during the YA through the provision of tailored employability modules;

- create a framework for reflection on and articulation of these skills;

- facilitate students' awareness of the transferability of these skills into the graduate job market. 


\section{What we did}

\subsection{Information gathering, interviews with Year Abroad Returners}

The MFL students interviewed had completed YA internships in France and Mexico and had had the opportunity to develop 'soft skills' in a work environment. It was apparent that until they were interviewed for this project they had not reflected on that development. They were aware of soft skills and the importance of these during the recruitment process and in the workplace, but needed prompting to identify them. However, the students had clearly reflected on residence abroad as a generally transformative experience.

Unsurprisingly, the students focused on communication skills as those which they felt had developed most during their YA. This was not restricted to making progress in the foreign language. As their principal objective whilst abroad was to develop their foreign language skills, the students had paid particular attention to language and its use. By observing and listening to colleagues - 'soft skills' in themselves - students had gained insight into more subtle aspects of communication and how communication impacts on the creation of a positive working environment. The students also felt they were in a privileged position; colleagues spoke more freely around them. One student commented that she "knew all the gossip" and that her colleagues sometimes seemed to forget she was there when discussing work related issues. The reasons for this are unclear: perhaps an underestimation of the students' understanding or possibly because the students were not perceived as full members of the team, being short-term employees.

This sensitivity to language also provided opportunity for broader cultural observations, for example, regarding formality and politeness in the workplace and the relationship between this and professional hierarchy. Students commented that their work environments seemed more formal than those in the UK, but acknowledged that their experience of comparable UK environments was limited. Conversely, one student completing an internship in Mexico contrasted the 
formality she noted in some aspects of her work environment with an exuberant friendliness and what she perceived as a good number of colleagues' desire to do "as little as possible". While noting these cultural differences, students stressed that these were personal observations and did not necessarily extend to other workplaces. It was apparent that the students had become sophisticated cultural observers and that - as they noted - this recognition of cultural difference had a profound and positive impact upon them. On return from the YA, they felt more open to other cultures and had become increasingly flexible in their personal and professional attitudes, and more accommodating to others in team-working environments.

Finally, the most significant effect of residence abroad was a greater willingness to take on challenges and an improved ability to overcome them. The students saw the YA itself as a positive but challenging experience, and, having overcome many individual challenges while abroad, they were more confident, resilient and independent. They also saw the practical side to this ability: being able to plan, prioritise, and self-set deadlines - effectively to project manage - underpinned by the confidence that they could achieve, as one student said, anything she set her mind to. Interestingly, the students struggled to give specific examples of how the skills developed had led them to work/behave differently since returning, but rather felt that the experience had impacted on every aspect of their personal, academic and professional lives.

\subsection{The provision of tailored employability modules to prepare students for soft skills development during the YA}

The interview results were combined with research into the employment challenges faced by Humanities students (AGR, 2013; HESA, 2014). Three key aims were identified to support the skills development of MFL undergraduates:

- Students must learn to recognise how they are developing soft skills, and which skills they are developing, before they leave for their YA. 
- This learning must be self-determined, to ensure that students are able to continue while away from campus.

- Students must be aware of how their YA skills transfer into the graduate job market (British Academy/UCML, 2012).

The second year employability module was created during summer 2015 to facilitate the first and second aims. Through the second year module, MFL students are encouraged to step outside their comfort zone and try new activities, including internships. The first session focusses on e-portfolios, used to facilitate independent reflection on skills development. Students learn about e-portfolios on a conceptual level, alongside why they should use them (Yorke \& Knight, 2006). E-portfolios enhance students' awareness of their learning in relation to skills rather than grades, encouraging them to link skills with experience and to evidence development through various media - blogs; photography; videos; social networks. Students are shown a demonstration of how to setup the preferred e-portfolio, Pathbrite (www.pathbrite.com), and a number of Pathbrite 'case studies', created by current undergraduate Humanities students, evidence how the e-portfolio can work with students' curricular, co-curricular, and extracurricular activity. In subsequent sessions students are set tasks to help build their e-portfolio, motivating them and encouraging increased self-awareness. Moreover, MFL students are encouraged to continue building e-portfolio content during their YA, creating an evidence base for job applications and interviews on their return. All e-portfolio activity is supported by a 'Resources and Advice' page in the module's Virtual Learning Environment (VLE) and a dedicated postgraduate teaching assistant.

The final aim - that MFL students must be aware of how their YA skills transfer into the graduate job market - is achieved through the module VLE. The site houses information which helps students to gauge 'What employers want', including internal and external resources, provided by the University Careers Service, The Guardian, TargetJobs and Milkround. The VLE also hosts links to skills-building resources, based on the transferable skills list on the University's Opportunity Profiles 'OPUS' website (http://opus.soton.ac.uk), demystifying 
such terms as 'resilience' while helping MFL students to understand how they demonstrate their skills. A collection of work experience, volunteering, and internship opportunities encourage students to get off-campus experience before their YA, in order to build confidence in existing abilities, such as communication with people from different cultures and backgrounds.

\subsection{The creation of a framework for reflection and articulation on YA-developed skills through the launch of an interactive online resource for students}

The REALIE website was created in 2012 by the Centre for Languages, Linguistics and Area Studies (LLAS) and the Modern Languages Department at the University of Southampton. During summer 2015, the Faculty employability team undertook to update the REALIE site, creating an interactive employability resource for undergraduate students embarking on a YA. An MFL student partner was recruited to redesign and develop the website before re-launching REALIE at the start of the 2015/16 academic year.

REALIE provides information for MFL students before, during, and after the YA. It helps students to identify, develop and demonstrate skills gained whilst studying and/or working overseas by highlighting how the YA experience can be used to develop skills and increase employability. Resources are tailored specifically to the three YA choices: English Language Assistant for the British Council; studying at a partner university as an ERASMUS student; or on a work placement. In order to create a resource which is both interactive and studentled, a blogging platform was incorporated into the REALIE site. Via the blog, a selection of current third year MFL students share their experiences, advice, and the skills they develop throughout their time abroad. Bloggers are able to reflect on their own growing skillset whilst sharing information and advice with their peers.

In the first semester, YA bloggers share their experiences on the 'culture shock', the challenges they face and how they overcome them, and the skills they 
develop personally, professionally, and socially. Each blogger shares personal perspectives, focussing on skills development and employability. In the first few months abroad, bloggers noted developments in their communication, networking, project management, self-management and personal effectiveness skills. As one REALIE blogger reported: "We are developing our organisational skills like never before, completing tasks that are not dissimilar to the sort of challenges we'll have to one day face in the workplace". Furthermore, students working abroad have highlighted the differences in foreign working culture: a female blogger stated that she has learnt "to speak up without being afraid to do so in a new environment".

REALIE has been created by students, for students and will soon feature a new reflective tool to consolidate the site's aims. Designed for both REALIE bloggers and YA students, this tool will encourage them to think about the professional transition they are undergoing during their YA, how this has developed, and the ways in which it will become useful in future employment.

\section{Discussion and conclusion}

This case study has identified that MFL students are greatly advantaged by their YA in the acceleration of their professional skills development, but that they do not always recognise this development as directly related to their employability. The creation of the Year Two Employability Module and the REALIE web resource facilitate a gradual, escalating awareness of the professional boost that a YA can give undergraduate students, encouraging self-reflection and bespoke growth. Bringing a student's existing achievements and skills together using Pathbrite gives them confidence in their personal as well as linguistic abilities, which in turn encourages them to make the most of the YA from the start.

Future work to enhance MFL employability will include case studies from students who have been REALIE bloggers, and reflection interviews with YA returners who have engaged with REALIE and the Year Two module, to gauge 
impact across the pilot year. Feedback from interviews and case studies, along with input from MFL colleagues and careers staff, will contribute to further development of YA employability support over summer 2016 and the creation of a final-year employability module.

\section{References and links}

AGR. (2013). The AGR Graduate Recruitment Survey 2013: Winter Review. Association of Graduate Recruiters. Retrieved from http:/www.agr.org.uk/write/Documents/Surveys/ The_AGR_Graduate_Recruitment_Survey_2013_Winter_Review.pdf

AGR/CIHE. (2011). Global Graduates into Global Leaders. Association of Graduate Recruiters (AGR) and Council for Industry and Higher Education (CIHE).

British Academy/UCML. (2012). Valuing the year abroad. Position Paper.

Havergal, C. (2015). UK engagement survey: universities have limited impact on students' 'soft' skill development. Times Higher Education. Retrieved from https://www. timeshighereducation.com/news/uk-engagement-survey-universities-have-limitedimpact-students-soft-skill-development

HESA. (2014). 2012/13 UK performance indicators - Employment of graduates. Higher Education Statistics Agency. Retrieved from https:/www.hesa.ac.uk/pr/3271-pressrelease-206

Leggott, D., \& Stapleford, J. (2004). Enhancing student awareness of employability skills through the use of progress files [online]. Leeds Metropolitan University. Retrieved from https://www.llas.ac.uk/resources/paper/2279\#toc_0

Mitchell, R., Tracy-Ventura, N., \& McManus, K. (2015). Social interaction, identity and language learning during residence abroad. EuroSLA, the European Second Language Association. Retrieved from http://www.eurosla.org/eurosla-monograph-series-2/socialinteraction-identity-and-language-learning-during-residence-abroad/

REALIE: Residence and Employment Aboard, Leading to International Employability. Retrieved from http://www.realie.org_

Small, T., \& Deakin Crick, R. (2008). Learning and self-awareness: an enquiry into personal development in higher education. The ViTaL Development \& Research Programme Report No. 8. University of Bristol. Retrieved from http://learningemergence.net/wp-content/ uploads/2014/02/ViTaL_RDP_Report_08.pdf 
Yorke, M., \& Knight, P. T. (2006). Learning \& employability series one: embedding employability into the curriculum [online]. The Higher Education Academy. Retrieved from http://www.employability.ed.ac.uk/documents/Staff/HEABriefings/ESECT-3-Embedding employability_into_curriculum.pdf 


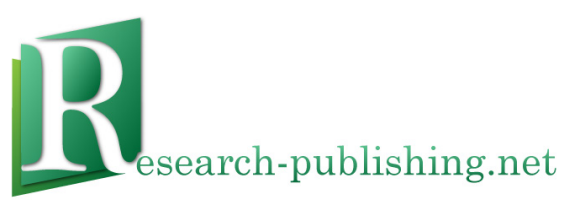

Published by Research-publishing.net, not-for-profit association Dublin, Ireland; Voillans, France, info@research-publishing.net

(C) 2016 by Erika Corradini, Kate Borthwick, and Angela Gallagher-Brett (collective work)

(C) 2016 by Authors (individual work)

Employability for languages: a handbook

Edited by Erika Corradini, Kate Borthwick, and Angela Gallagher-Brett

Rights: All articles in this collection are published under the Attribution-NonCommercial -NoDerivatives 4.0 International (CC BY-NC-ND 4.0) licence. Under this licence, the contents are freely available online as PDF files (http://dx.doi.org/10.14705/rpnet.2016.cbg2016.9781908416384) for anybody to read, download, copy, and redistribute provided that the author(s), editorial team, and publisher are properly cited. Commercial use and derivative works are, however, not permitted.

\section{(9) $\Theta \Theta \Theta$}

Disclaimer: Research-publishing.net does not take any responsibility for the content of the pages written by the authors of this book. The authors have recognised that the work described was not published before, or that it was not under consideration for publication elsewhere. While the information in this book are believed to be true and accurate on the date of its going to press, neither the editorial team, nor the publisher can accept any legal responsibility for any errors or omissions that may be made. The publisher makes no warranty, expressed or implied, with respect to the material contained herein. While Research-publishing.net is committed to publishing works of integrity, the words are the authors' alone.

Trademark notice: product or corporate names may be trademarks or registered trademarks, and are used only for identification and explanation without intent to infringe.

Copyrighted material: every effort has been made by the editorial team to trace copyright holders and to obtain their permission for the use of copyrighted material in this book. In the event of errors or omissions, please notify the publisher of any corrections that will need to be incorporated in future editions of this book.

Typeset by Research-publishing.net

Cover design and frog picture by (C) 2016 Raphaël Savina (raphael@savina.net)

Cover illustration by (C) 2016 Nicolas Fenix (www.nicolasfenix.com)

ISBN13: 978-1-908416-37-7 (Paperback - Print on demand, black and white)

Print on demand technology is a high-quality, innovative and ecological printing method; with which the book is never 'out of stock' or 'out of print'.

ISBN13: 978-1-908416-38-4 (Ebook, PDF, colour)

ISBN13: 978-1-908416-39-1 (Ebook, EPUB, colour)

Legal deposit, Ireland: The National Library of Ireland, The Library of Trinity College, The Library of the University of Limerick, The Library of Dublin City University, The Library of NUI Cork, The Library of NUI Maynooth, The Library of University College Dublin, The Library of NUI Galway.

Legal deposit, United Kingdom: The British Library.

British Library Cataloguing-in-Publication Data.

A cataloguing record for this book is available from the British Library.

Legal deposit, France: Bibliothèque Nationale de France - Dépôt légal: juin 2016. 